\title{
The Effect of Asset Quality and Financial Performance on Non Performing Loans (NPLs) of Rural Banks in Indonesia
}

\author{
Dwinisa Nur Hamdillah ${ }^{1}$, Budi Purwanto ${ }^{2}$, Wita Juwita Ermawati ${ }^{2}$ \\ \{dwinisa_hamdillah@apps.ipb.ac.id ${ }^{1}$, budipurwanto@apps.ipb.ac.id ${ }^{2}$, witaman@apps.ipb.ac.id ${ }^{2}$ \} \\ Departement of Management, Faculty of Economic and Management, IPB University ${ }^{1,2}$
}

\begin{abstract}
The number of Rural Banks in Indonesia continued to decrease during 2015-2019, even when its assets increase positively. Credit is the primary source of income for rural banks, so most assets are placed in lending. However, growth in lending was followed by higher growth in problematic lending so that the level of Non-Performing Loans (NPLs) continued to increase and exceeded the maximum limit set by Bank Indonesia. It indicates that Rural Banks has not worked optimally in Indonesia, especially in facing the credit risks. This study aimed to analyze the effect of assets qualities consisting of total assets and earning assets quality and financial performance consisting of productivity, efficiency, and profitability on NPL over the 2015-2019 periods. This research used secondary data that is a financial report publication published by Otoritas Jasa Keuangan. Research's sample used 320 Rural Banks all over Indonesia selected by purposive sampling method. The data were analyzed with regression data panel. The results showed that total assets did not affect NPL. Earning assets quality had a positive effect on NPL, while productivity, efficiency, and profitability negatively affected NPL.
\end{abstract}

Keywords: Asset Quality, Financial Performance, Non-Performing Loans, Rural Bank..

\section{Introduction}

Rural banks are financial institutions that focus on financing and lending to the micro small and medium enterprises sector. Rural banks are banks that carry out business activities conventionally or based on sharia principles, which in their activities do not provide services in payment traffic [1]. In contrast to commercial banks, rural banks have more narrow activities because rural banks are prohibited from accepting current accounts, foreign exchange activities, and insurance. Nevertheless, rural banks have become an essential financial institution for the micro small and medium enterprises sector in their 
easy lending. It makes the most of the rural banks' productive assets placed for lending.

Indonesian Banking Statistics showed that from 2015 to 2019, the number of rural banks declined. In 2015 the number of rural banks was 1637, while in September 2019, it was only 1,578. This decrease occurred despite the total assets showing positive growth with an average growth of $9.8 \%$. It indicates that rural banks have not been optimal in managing their assets, making them vulnerable to liquidation. Risk assets such as total loans are a significant part of bank assets [2]. As a financial institution with the main activity of collecting and distributing funds, rural banks are faced with credit risk. NonPerforming Loan (NPL) is a ratio to measure, estimate, and find out credit risk that might occur [3]. Increasing non-performing loans could affect banks' operating activities with the worst possible of banks will be bankrupt [4]. Total loans disbursed by rural banks showed growth from 2015 to 2019. However, this credit growth was followed by higher non-performing loan growth, which caused NPLs to increase above 5\%. NPL increased from $5.37 \%$ in 2015 to $6.81 \%$ in 2019. This condition exceeds the maximum limit set by Bank Indonesia, indicating that rural banks have poor NPL performance. Poor NPL performance endangers the viability of banks, making banks vulnerable to liquidation.

Bank risk generally stems from weak assets, so asset quality is an essential component of the bank's credit profile [5]. The asset quality variables used are Total Assets (TA) and Earning Asset Quality (EAQ). Total assets indicate the bank size, where an increase in assets owned by the bank can increase the potential for profit if operational activities are carried out appropriately. However, increasing assets can increase the potential for problem loans if they are not adequately monitored. Earning Assets Quality is needed to determine the probability of a credit default [6]. Microeconomic factors that affect NPLs can be seen from the financial ratios that measure the bank's financial performance [7]. The financial performances used in this study are productivity, efficiency, and profitability.

Loan to Deposit Ratio (LDR) is used by previous researchers to measure the ratio of credit extended amount to the funds collected by banks. This ratio is used to measure the level of bank productivity in providing credit from funds collected from third parties. LDR decreased from $77.81 \%$ in 2015 to $75.36 \%$ in 2017 and increased to $77.81 \%$ in September 2019. Previous studies show that the higher the LDR can reduce the NPL [6] [7] [8]. The strategy to increase LDR by increasing lending will reduce non-performing loans when loans are on target. It happens because the NPL is the ratio between the number of problem loans and the total loans provided by banks. However, 
different results show that a high LDR will increase the chances of problem loans resulting in higher NPL levels [2, 9-10].

The financial ratio that measures the efficiency of the bank's performance is BOPO (Operating Expense Operating Income). BOPO is a ratio of operating expense to operating income that measures the efficiency and the ability of banks to carry out their operations. In the last five years, the value of BOPO has fluctuated and three years of which are more than $100 \%$, indicating that the bank has not been efficient in carrying out its business activities. Previous studies show that the higher the BOPO, the higher the NPL [4, 6, 8, 11-13]. Banks are inefficient when operational costs increase but cannot reduce problem loans [12]. If the bank is efficient, the bank will have the opportunity to get the optimal profit, increasing the amount of credit provided to reduce the bank's credit risk.

The last financial ratio used in this study was Return on Assets (ROA), a ratio that measures profitability. ROA decreased from $2.71 \%$ in 2015 to $2.29 \%$ in September 2019. Banks with high profitability showed an ability to create income, so they were less involved in offering risky loans [14]. Previous studies have shown that when ROA decreases, banks start investing in highrisk projects so that the level of NPL increases [9,15-18]. The significant negative impact of ROA on non-performing loans shows that risk-taking is reduced in banks that show a high level of performance. Increasing profits will increase the number of reserve funds for risk management and mitigate risk to reduce NPL [18].

The reason above showed that the number of rural banks in Indonesia declined from 2015 to 2019, while the total assets increased. This asset growth was also followed by suboptimal financial performance. However, the majority of rural bank's productive assets are credit. It makes rural banks face high credit risk as measured by the Non Performing Loans (NPLs). Therefore the study aims to analyze the effect of asset quality and financial performance on NPLs of rural banks in Indonesia.

\section{Literatur Review}

Credit risk is the risk caused by the inability of the debtor to fulfill his obligations as required by the creditor. Credit risk is measured by Non Perfroming Loan. NPLs are conditions when the customer is unable to pay part or all of his obligations to the bank as promised. This situation causes bank losses, because the funds that have been distributed and interest income are not received, resulting in a decrease in total income. 
Asset quality shows management competence in controlling credit risk associated with bank assets. Asset quality is an attempt to assess the types of assets owned by a bank [5] Asset quality assessment is an assessment of the condition of bank assets and the adequacy of credit risk management. Asset quality assessment is conducted to evaluate the condition of bank assets and the adequacy of credit risk management.

Performance is one of the important factors that shows the effectiveness and efficiency of banking in achieving its objectives. The financial performance of the bank shows the success of the bank in attracting public funds and channeling them through the implementation of predetermined management. Productivity is a measure of the company's ability to use its inputs to produce output. This variable is measured by the Loan to Deposit Ratio (LDR) which shows how the bank has used the funds raised to provide loans to its customers. Efficiency shows the bank's ability to minimize costs against the income received. Profitability is a performance indicator that shows a company's ability to generate profits during a certain period [5].

Several studies use the variables of asset quality and financial performance to identify factors that influence non-performing loans in several countries. Rajha [19] examines the determinants of banking sector in Jordan. The study was conducted because of the rising level of problem loans (NPL) in Jordan since the global financial crisis put intense pressure on the bank's balance sheet. The results showed that banks that had high NPLs in the previous year would have high NPLs in the current year. Besides, NPL is influenced by the LTA ratio, the global financial crisis, economic growth, and inflation. At the same time, bank size and interest rates do not show a significant effect on NPLs.

El-Maude [2] examined the relationship and influence of specific factors of banks and macroeconomics on NPLs in 10 commercial banks in Nigeria during the period 2010 to 2014 . Injuries suffered due to bad credit losses have reduced the capital position of many banks, which can cause the Nigerian banking industry's failure. The correlation results show that asset return (ROA), capital adequacy ratio (CAR), and average loan rate (ALR) are negatively correlated with NPLs. On the other hand, total loans to deposits (LTD) and inflation (INFL) and Bank size (BZ) are positively correlated with NPLs. Significant factors are shown by LTD and the size of the bank, which has a positive influence.

In the same year, Kupcinskas [15] examined the factors influencing NPLs in the Baltic and Nordic countries from 1998 to 2014. This research was conducted because during the global financial crisis from 2007 to 2008, increased NPL occurred in these countries. The results show that real GDP 
growth, unemployment rate, and ROA are the variables that most affect NPLs in the Baltic and Nordic regions. Banking specific variables (NIM, ROA, ROE) are found as weak explanatory variables for NPL. While macro variables were not significant at all in the model for the panel data analyzed.

Similar research was conducted by Wood and Skinner [9] at the Commercial Bank in Barbados for the period 1991 to 2015. The study was conducted because of the global financial crisis in 2008 increased the ratio of bad loans to total loans. They explain that macroeconomic factors and bankspecific factors can influence problem loans. The results showed that GDP growth, unemployment rates, and real interest rates had a significant negative impact on problem loans. However, inflation has no effect on NPL commercial bank in Barbados. In comparison, all bank-specific variables in the model were found to be statistically significant. Empirical results show that there is a negative and significant effect of ROA and ROE on NPL. At the same time, LTD and CAR have a significant positive effect on NPL.

In Indonesia, there are also many studies on NPL. Adhadini [2], Riyadi [6], Mada [8], and Wardhana [13] researched the factors influencing NPLs on conventional commercial banks listed on the IDX. The results of the study found quite diverse. According to Adhadini [2] and Wardhana [13], bank size was found to have a positive influence on NPL. However, Mada [8] provides evidence that bank size has a negative influence on NPL. CAR has a significant negative effect on NPL [8]. The opposite was shown by Riyadi [6]. However, Adhadini [2] and Wardhana [13] did not find a significant effect between CAR on NPL. Something similar happened to the LDR ratio. According to Riyadi [6] and Mada [8], LDR negatively influences NPL. Adhadini's findings [2] show the opposite. Different results with Wardhana [8], LDR was found not to affect NPL. All research results show that BOPO, interest rates, and credit growth positively influence NPL. In contrast, asset quality has a negative influence on NPL [6].

A recent study was conducted by Khan [17] to examine the determinants of NPL in Pakistan's banking sector during the period 2005 to 2017. This research was carried out because the financial crisis in 2007 and 2008 resulted in financial market instability that was marked by an increase in bad loans in the sector banking. The results show that operating efficiency and profitability indicators have a negative relationship with NPL and are statistically significant, while capital adequacy and income diversification have a negative relationship with NPL but are not statistically significant.

Based on previous studies, it is known that an increase in NPL can be dangerous for the banking sector. The increase in NPLs puts pressure on the banking balance sheet and can lead to bank failures, so it is vital to examine 
the factors that affect NPLs. The results showed that most of the factors came from internal or specific factors of the bank. However, there are still different research results, so it is difficult to conclude how these factors affect NPL. Differences in research results are the basis of the importance of this study to confirm these differences. Also, most researches are conducted at commercial banks. Research on rural banks is still rare, while the scope of rural banks' business is smaller than that of commercial banks, which causes rural banks to have higher credit risk. Therefore, this study examines the effect of asset quality and financial performance on NPLs of rural banks in Indonesia.

\section{Methodology}

\subsection{Data}

This study population comprises rural banks listed in Otoritas Jasa Keuangan in September 2019 for 1578 banks. This research was conducted on 320 rural banks in Indonesia selected using the purposive sampling method with the criteria used are as follows: (1) Rural banks are listed in Otoritas Jasa Keuangan (2) Rural banks are published annual financial statements from 2015 to 2019, and (3) Rural banks have complete variable data needed in this study.

\subsection{Variabel Definition}

The following is the definition of each indicator used in this study:

1. Non Performing Loans - NPL is used to measure the ratio of the number of problem loans to the total loans granted. Problem loans are classified as doubtful, substandard, and bad loans [20].

2. Total Assets - Assets are resources controlled by rural banks that are expected to be a source of future economic benefits [20]. Total assets describe the bank's size using a natural logarithm proxy $(\ln )$ of total assets.

3. Earning Assets Quality - EAQ is used to measure the ratio of earning assets classified to earning assets as regulated in the legislation's provisions governing the procedures for evaluating the soundness of rural banks [20].

4. Loan to Deposit Ratio (LDR) - LDR is used to measure the ratio of loans to third party funds in rural banks where credit is the total credit given to third parties (not including credit with other banks), and third party funds include savings, and deposits (not including interbank) [20]. 
5. Operating Expenses Operating Income (BOPO) - BOPO is used to measure the ratio of operating expenses to operating income to determine the efficiency and ability of the rural banks in carrying out its operational activities by dividing between total operating expenses and total operating income [20].

6. Return on Assets (ROA) - ROA is used to measure rural bank management's ability to obtain overall profits by dividing profit before tax by the average total assets [20].

\subsection{Reasearch Hypotheses}

Effect of Total Assets on Non-Performing Loans. According to El-Maude et al. [2] and Barus and Erick [11], the larger the size of the bank, the greater the credit risk the bank has. The increase in assets can increase the potential for non-performing loans if the supervision is not appropriate. This happens because banks with large assets will have large loans.

H1 : Total assets have a positive effect on NPL

Effect of Earning Asset Quality on Non-Performing Loans. Riyadi et al. [6] and Aryani et al. [21] show that the higher EAQ, the higher probability of credit failure so that the NPL also increases. This happened because EAQ increased due to earning assets classified as higher, this showed that there was an increase in loans that had the potential to cause non-performing loans.

H2 : Earning Asset Quality has a positive effect on NPL

Effect of Productivity on Non Performing Loans. According to Riyadi et al. [6], the strategy of increasing LDR by increasing lending will reduce nonperforming loans and open up opportunities to increase the percentage of credit quality channeled so that NPLs can be reduced.

H3 : Productivity has a negative effect on NPL

Effect of Efficiency on Non Performing Loans. According to Ratnasari [12] if a bank has a low BOPO which indicates operational efficiency, the bank will have the opportunity to get optimal profit, increase the amount of credit extended, and improve service to customers so as to reduce bank credit risk.

H4 : Efficiency has a negative effect on NPL

Effect of Profitability on Non-Performing Loans. Return on Asset (ROA) is a profitability ratio that shows a bank's ability to generate profits. the increase 
in profit will increase the reserves for risk management and the ability of banks to mitigate risks will also increase so that NPL can be reduced [18].

H5 : Profitability has a negative effect on NPL.

\subsection{Method of Analysis}

The data processing and analysis method used in this study is panel data regression analysis. Panel data is a combination of cross-section data and time series. This study uses 320 cross-section data and time series for five years, from 2015 to 2019. Data analysis was performed using Eviews9 software. The following is a panel data regression modeling in this study:

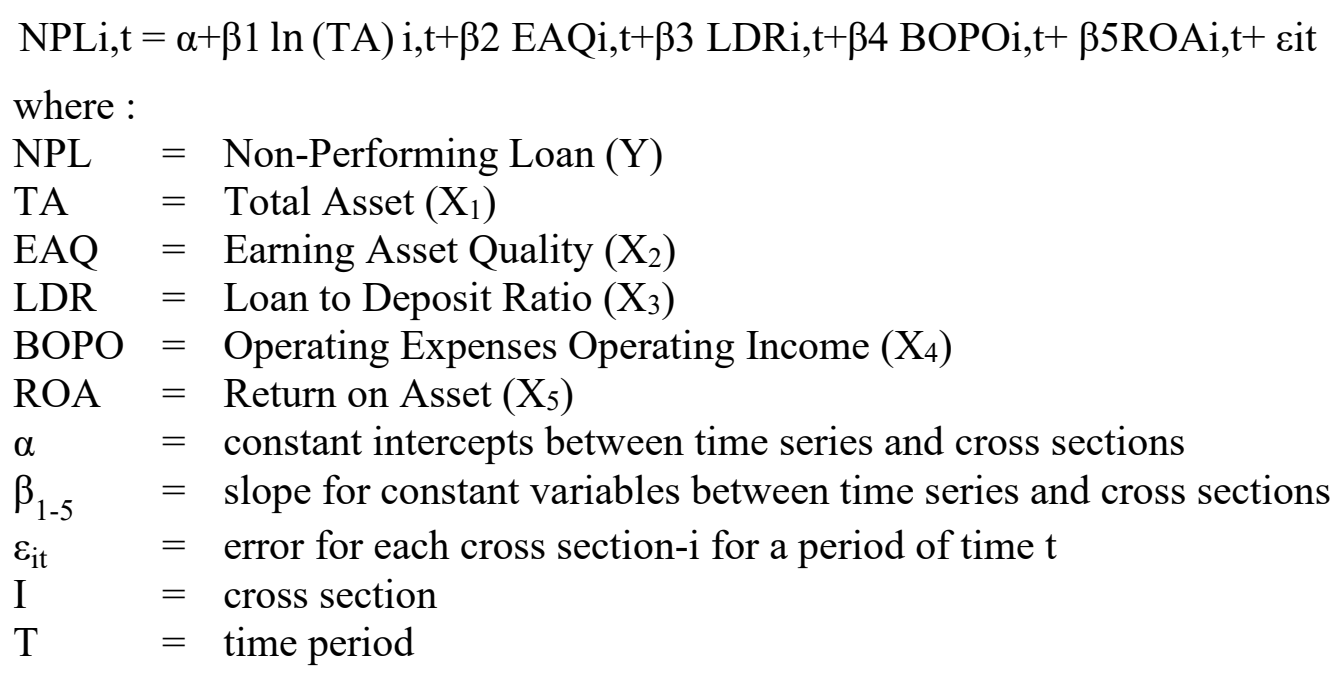

\section{Result and Duscussion}

\subsection{Rural Banks in Indonesia}

Rural banks have NPLs that have increased from 2015 to 2019 and exceed the maximum limit set by Bank Indonesia of 5\% so that it can be interpreted that problem loans are very vulnerable to rural banks. Total assets increased from 2015 to 2019, with an average growth of $9.1 \%$. Besides, an increase in total assets was followed by increased earning asset quality with an average growth of 3\%. It shows that an increase in the placement of productive assets does not guarantee an increase in the likelihood of receiving investment in these productive assets. The LDR ratio decreased from 2015 to 2018 and 
increased in 2019. Nevertheless, LDR tends to be stable at $75-80 \%$. The decline in the LDR occurred because the increase in funds raised was higher than the increase in credit provided. It shows that rural banks have not maximized the funds raised in lending activities. The BOPO ratio has increased, and in the last two years, it exceeds the maximum limit based on BI regulations. A high BOPO ratio indicates that banks are not efficient in carrying out their business activities. Thus, it can be concluded that rural banks have not been efficient in controlling costs over their operating income. At the same time, the ROA ratio showed a downward trend from 2015 to 2019 , with an average growth of $-8.95 \%$. The decrease in ROA shows that rural banks' ability to generate profits from their assets is reduced. Data on asset quality, financial performance, and NPL of rural banks in Indonesia can be seen in Table 1.

Table 1. Quality asset, financial performance, and NPL of rural banks in Indonesia

\begin{tabular}{ccccccc}
\hline Years & $\begin{array}{c}\text { Total Asset } \\
\text { (Rp. thausands) }\end{array}$ & $\begin{array}{c}\text { EAQ } \\
(\%)\end{array}$ & $\begin{array}{c}\text { LDR } \\
(\%)\end{array}$ & $\begin{array}{c}\text { BOPO } \\
(\%)\end{array}$ & $\begin{array}{c}\text { ROA } \\
(\%)\end{array}$ & $\begin{array}{c}\text { NPL } \\
(\%)\end{array}$ \\
\hline 2015 & 76167469 & 7.63 & 80.67 & 89.22 & 3.01 & 6.39 \\
2016 & 86240950 & 8.25 & 78.18 & 89.72 & 3.25 & 7.09 \\
2017 & 95258978 & 8.22 & 75.73 & 91.19 & 3.17 & 7.84 \\
2018 & 102851506 & 7.71 & 75.22 & 94.50 & 1.74 & 8.50 \\
2019 & 107754262 & 8.51 & 77.97 & 99.86 & 1.80 & 8.86 \\
\hline
\end{tabular}

\subsection{Empirical Result}

The effect of asset quality and financial performance on Non-Performing Loans (NPLs) of rural banks in Indonesia is known by conducting panel data regression analysis. Panel data regression is performed using three approaches, i.e., Pooled Least Square (PLS), Fixed Effect Model (FEM), Random Effect Model (REM). Based on the Chow test and the Hausman test, it was concluded that the best model to be used was the Fixed Effect Model (FEM). Before conducting a regression evaluation with the Fixed Effect Model (FEM), the classical assumption test must be done. The classical assumption tests include normality, multicollinearity, and heteroscedasticity. The normality test is performed using the Jarque-Bera test. Based on the JarqueBera test results, the probability value of Jarque-Bera is 0.050868 or greater than $\alpha=0.05$. It means that residuals are normally distributed. 
Multicollinearity is known by using the Correlation matrix. Based on the multicollinearity matrix, it is known that the correlation value is less than 0.90 . It means that the independent variables have no multicollinearity problems. Heteroscedasticity can be determined by the residual graph method. Based on the test, the histogram does not form a specific pattern so that it can be concluded that the residual variance has been homogeneous.

The estimation results of the Fixed Effect Model in Table 3 show the RSquared value of 0.9497 . It means that the NPL can explain $94.97 \%$ of the diversity of TA, EAQ, LDR, BOPO, and ROA. Simultaneous Significance Test shows the probability value (F-statistics) is 0.0000 or less than 0.05 , meaning that the model is feasible at the real level of 5 percent. It shows that simultaneously the independent variables, including total assets, EAQ, LDR, BOPO, and ROA, have a significant effect on NPL. The results of panel data regression analysis can be seen in Table 2 .

Tabel 2. The Effect of Asset Quality and Financial Performance on Non Performing Loans (NPLs) of Rural Banks in Indonesia

\begin{tabular}{lcccc}
\hline Variable & Coefficient & Std. Error & t-Statistic & Prob. \\
\hline TA (X1) & 0.1121 & 0.0884 & 1.2674 & 0.2053 \\
EAQ (X2) & 0.4747 & 0.0081 & 58.965 & 0.0000 \\
LDR (X3) & -0.0248 & 0.0024 & -10.226 & 0.0000 \\
BOPO (X4) & 0.0052 & 0.0008 & 6.1818 & 0.0000 \\
ROA (X5) & -0.0350 & 0.0060 & -5.8811 & 0.0000 \\
C & 3.5176 & 1.4821 & 2.3734 & 0.0178 \\
\hline R-squared & 0.9497 & & & \\
F-statistic & 74.232 & & & \\
Prob(F-statistic) & 0.0000 & & &
\end{tabular}

The effect of total assets on NPL. Based on the estimation results using the Fixed Effect Model, Total Assets (TA) have a coefficient of 0.1121 with a probability of 0.2053 . These results showed that total assets do not affect NPL at the 5 percent significance level, so the first hypothesis is rejected. It happens because banks with high assets are considered capable of taking risks due to various situations faced by banks related to their operations to reduce NPLs. On the other hand, banks with high assets will increase the potential for credit risk due to increased lending. This result is different from Adhadini [4], which states that the higher the assets, the greater the volume of loans extended so that the level of problem loans will be higher. This result is in line with Riyadi [6], which shows that the size of a bank's assets does not cause the bank's NPL to increase or decrease. This result is similar to Rajha's study [19], which fails to assume that large banks take excessive risks by providing loans to low- 
quality borrowers to have more NPLs. This condition indicates that the bank's size is not able to show the ability of banks to manage asset quality.

The effect of Earning Asset Quality on NPL. Earning Assets Quality (EAQ) has a coefficient of 0.4747 with a probability of 0.0000 or less than 0.05 . It shows that Earning Asset Quality has a positive effect on NPL at a significance level of 5 percent. Thus, the second hypothesis is accepted. The quality of Earning Assets continuing to increase shows the weakness of assets that can cause credit risk. The results showed that the worse the quality of assets, the higher the potential risk faced by banks due to lending and investment of bank funds in different portfolios. This study supports the study conducted by Riyadi [6] and Aryani [21] which states that the higher the EAQ, the higher the probability of credit failure so that the NPL also increases. It happens because of the quality of Earning Assets increases due to earning assets classified as getting higher, increasing loans that have the potential to cause failure, or are classified as special attention, substandard loans, doubtful loans, and bad loans. This condition emphasizes that quality is more important than the number of assets in the continuity of rural bank's business activities in Indonesia.

The effect of Loan to Deposit Ratio on NPL. Estimation results on the Loan to Deposit Ratio (LDR) variable show results with a coefficient of -0.0248 and a probability of 0.0000 or less than 0.05 . These results show that the LDR has a negative effect on NPL at the 5 percent significance level so that the third hypothesis is accepted. This significant negative result occurs because the data shows a declining LDR causing NPL to increase. This finding shows that it is increasingly productive to channel funds in the form of loans, increasing opportunities to improve credit quality when lending is monitored correctly. The results of this study are in line with Riyadi [6] and Mada [8] which state that LDR will encourage lending that can reduce bad loans and open opportunities to increase the percentage of credit quality that is channeled if credit is distributed on target. This research is also in line with Firdausa [7] which states that maximizing the use of funds raised by banks in lending activities can reduce the problem loans faced by banks. It happens because the NPL is a ratio that measures the ratio between the number of problem loans with the total loans provided by banks. However, this result is different from previous studies which show that LDR has a negative effect on NPL $[2,4,9$ $11,14,22]$. 
The effect of Operating Expenses Operating Income on NPL. Operating Expenses Operating Income (BOPO) has a coefficient of 0.0052 with a probability of 0.0000 or less than 0.05 . These results show that BOPO has a positive effect on NPL at the 5 percent significance level, so the fourth hypothesis is accepted. This positive and significant effect shows that a high NPL ratio will follow banks with a high BOPO. The results of this study are in line with previous studies which show that the higher the BOPO, the NPL will increase $[4,8,11,13,22]$. It happens because the level of bank efficiency can reflect the level of quality management and effectiveness of the services implemented by the bank. The low quality of management also results in poor credit management processes that contribute to high NPLs. This research is also in line with Riyadi [6] and Ratnasari [12], which states that a high BOPO indicates a failure of banks to streamline their operational activities, resulting in problem loans. If the bank has a low BOPO that shows operational activities have been efficient, the bank will have the opportunity to get optimal profits, increase the number of loans extended, and improve services to customers to reduce bank credit risk. However, this result differs from the research of Argaw [14] Rachman [16], and Kumar [23], which shows that BOPO does not affect NPL.

The effect of Return on Asset on NPL. The last variable, Return on Assets (ROA), has a coefficient of -0.0350 with a probability of 0.0001 or less than 0.005 . These results show that ROA has a negative effect on NPL at a significance level of 5 percent. Thus, the last hypothesis can be accepted. The results of this study are in line with the research of Rachman [16] and Putri [18], which states that if there is an increase in profits, it will increase the reserve of funds as a preventive activity for risk management and risk mitigation to reduce NPL. This result is also in line with research by Wood and Skinner [9] and Khan [17], stating that profitability has a negative and significant impact on NPL. Based on his research, high NPLs are caused by bank decisions to start investing in high-risk projects, and as a result, the level of NPLs increases. However, the results of this study differ from El-Maude [2], and Wardhana [13], showing that there is no influence between profitability and NPL.

\section{Conclusion and Implications}

The results of panel data regression analysis show that the size of the assets does not affect NPL. Only Earning Assets Quality shows the effect of 
asset quality on NPLs. EAQ has a positive effect on NPL. The positive effect of EAQ on NPL shows that the worse the quality of assets, the higher the potential risk faced by banks due to bank lending. The results also concluded that all financial performance variables, such as productivity, efficiency, and profitability, significantly influenced NPL. Productivity measured by LDR shows a negative effect on NPL, which means that the more productive banks use the funds raised in lending activities, the lower the credit risk they face. BOPO has a positive effect on NPL, showing that the more efficient a bank is in carrying out its business, the lower the credit risk faced by banks. Profitability measured by ROA shows a negative effect on NPL, which means that the lower the bank's ability to generate profits, the higher credit risk.

Credit risk is a major problem for rural banks because lending is the main activity of rural banks in conducting their business. Therefore, from the results of the research conducted to overcome the NPL, which is the source of rural bank problems, it is necessary to maintain asset quality by improving the quality of its credit. Total assets show that the size of the rural banks does not affect credit risk. However, the majority of rural banks' earning assets are placed for lending, so it is essential to maintain asset quality. The results showed that the higher EAQ caused high NPLs. Therefore rural banks need to improve asset quality by overseeing fund allocation, resource and risk distribution, and reducing the EAQ ratio by maintaining credit quality so that the value of productive assets is classified as low.

Besides, to be able to reduce credit risk, rural banks need to improve financial performance. The negative effect of the LDR on the NPL shows that if the bank is more productive in lending, it will reduce credit risk if adequately monitored. In this case, the rural banks need to extend credit by selecting credit recipients and supervising loans granted so that lending does not increase problem loans. The results also showed that a high BOPO would result in a high NPL. It indicates that the more inefficient a bank is in managing its business, the higher the credit risk. Rural banks need to have a low BOPO to show that they are efficient in running their business. Therefore, rural banks also need to improve efficiency by controlling operational expenses to prevent expenses that exceed income, especially fundraising expenses. ROA has a negative effect on NPL, so rural banks need to increase profitability to have reserve funds to carry out preventive activities in managing risks and mitigating risks especially credit risk. Credit income is a source of income for rural banks, therefore rural banks need to increase interest income and increase credit collectability by ensuring debtors pay their debts according to the provisions. 
This research cannot prove all the hypotheses tested. Although conditions indicate that an increase follows an increase in NPL assets, statistically, it cannot be proven that total assets have a positive effect on NPLs, as shown by previous studies. Therefore, researchers can then conduct further research in order to be able to analyze the effect of total assets on NPL that cannot be explained in this study or use another approach. Besides, researchers can add other factors not found in this study, such as LAR, ROE, and NIM, so that research is more extensive and enriches the study.

\section{References}

[1] Act of The Republic of Indonesia Number 7 of 1992 Concerning Banking as Amanded by Act Number 10 of 1998

[2] El-Maude JG, Abdul-Rehman A, Ibrahim M. Determinants of Non-Performing Loans in Nigeria's Deposit Money Banks. Archives of Business Research. 2017; 5(1):74-88. doi:https://doi.org/10.14738/abr.51.2368

[3] Agustriana D. 2018. Analysis of Influence of Credit Growth, Bank Size, Liquidity Level, and Capital Ratio to Credit Risk in Go Public Conventional Banks Registered on the Indonesia Stock Exchange. Islamic University of Indonesia . 2018

[4] Adhadini ND. Analysis of the Effect of Bank Size, LDR, BOPO, Credit Growth, and CAR on Non-Performing Loans (Case Study in Conventional Commercial Banks Registered on the Indonesia Stock Exchange in 2010-2014). Diponegoro Journal of Management. 2016; 5(3):1-13

[5] Silvia SA. Effect of Asset Quality on Profitability in Islamic Banking in Indonesia. Journal of Islamic Economics. 2017; 2(1):53-80. doi: 10.29240/jie.v2i1.192

[6] Riyadi S, Iqbal N, Lauren N. Non Performing Loan Management Strategies at Go Public Commercial Banks. Jurnal Dinamika Manajemen. 2015; 6(1):84-96. doi: https://doi.org/10.15294/jdm.v6i1.4299

[7] Firdausa A. Effect of LAR, LDR and Total Loans on Non-Performing Loans at Rural Banks. IPB University. 2018

[8] Mada RP, Arfinto ED. Analysis of Factors Affecting Non-Performing Loans (NPL) in Indonesia (Studies in Conventional Commercial Banks Registered at Bank Indonesia in 2011-2014). Diponegoro Journal of Management . 2015; 4(3):1-11

[9] Wood A, Skinner N. Determinants of non-performing loans: evidence from commercial banks in Barbados. The Business and Management Review. 2018; 9(3):44-64

[10] Khafid M, Fachrurrozie, Anisykurillah I. Investigating the Determinants of NonPerforming Loan: Loan Monitoring As a Moderating Variable. International Conference on Economics, Business and Economic Education. 2020; 126-136. doi: https://doi.org/10.18502/kss.v4i6.6592

[11] Barus AC, Erick. Analysis of Factors Affecting Non-Performing Loans at Commercial Banks in Indonesia. Jurnal Wira Ekonomi Mikroskil. 2016; 6(2):113-122

[12] Ratnasari D. Analysis of Factors Influencing Non-Performing Loans in Rural Banks in Banyumas 2014-2016. IPB University. 2017

[13] Wardhana GW, Prasetiono. Analysis of Factors Affecting Non-Performing Loans. Diponegoro Journal of Management. 2015; 4(4):1-11 
[14] Argaw SA. Factors Affecting Non-Performing Loans: In Case of Commercial Bank of Ethiopia. Mekelle University. 2016

[15] Kupcinskas K, Paskevisius A. Key Factors of Non-Performing Loans in Baltic and Scandinavian Countries: Lessons Learned in The Last Decade. Ekonomika. 2017; 96(2):43-55. doi: https://doi.org/10.15388/Ekon.2017.2.10994

[16] Rachman RA, Kadarusman YB, Anggriono K, Setiadi RBank-specific Factors Affecting Non-performing Loans in Developing Countries: Case Study of Indonesia. Journal of Asian Finance, Economics and Business. 2018; 5(2):35-42. doi: https://doi.org/10.13106/jafeb.2018.vol5.no2.35

[17] Khan MA, Siddique A, Sarwar Z. Determinants of non-performing loans in the banking sector in developing state. Asian Journal of Accounting Research. 2020; doi: https://doi.org/10.1108/AJAR-10-2019-0080

[18] Putri M. Analysis of Factors Affecting Non-Performing Loans based on Types of Credit Use in Ownership of Commercial Banks in Indonesia. IPB University. 2015

[19] Rajha KS. Determinants of Non-Performing Loans: Evidence from the Jordanian Banking Sector. Journal of Finance and Bank Management. 2016; 5(1):54-65. doi: https://doi.org/10.15640/jfbm.v5n1a5

[20] Circular Letter of Otoritas Jasa Keuangan Number 8/SEOJK.03/2019 concerning Monthly Report of Rural Banks. Availabel at: https://www.ojk.go.id/id/regulasi/Documents/Pages/Laporan-Bulanan-Bank-PerkreditanRakyat/seojk\%208-2019.pdf

[21] Aryani Y, Anggraeni L, Wiliasih R. Factors That Influence Non-Performing Financing in Indonesian Sharia Commercial Banks Period 2010-2014. Jurnal Al-Muzara'ah. 2016; 4(1):44-60

[22] Suryanto. Non Performing Loans on Regional Development Bank in Indonesia and Factors that Influence. Mediterranean Journal of Social Sciences. 2015; 6(4):280-287. doi: https://doi.org/10.5901/mjss.2015.v6n4p280

[23] Kumar RR, Stauvermann J, Patel A, Prasad SS. Determinants of non-performing loans in banking sector in small developing island states. Accounting Research Journal. 2018; 31(2):192-213. doi: https://doi.org/10.1108/ARJ-06-2015-0077

[24] Bank Indonesia. Bank Indonesia Regulation Number 15/2 / PBI / 2013 concerning Determination of Status and Follow-Up to Conventional Commercial Bank Supervision. Availabel at: https://www.bi.go.id/id/peraturan/perbankan/Pages/PBI_15 2_PBI 2013.aspx

[25] Otoritas Jasa Keuangan. Indonesian Banking Statisic September 2019 . Available at: https:/www.ojk.go.id/id/kanal/perbankan/data-dan-statistik/statistik-perbankanindonesia/Pages/Statistik-Perbankan-Indonesia---September-2019.aspx 